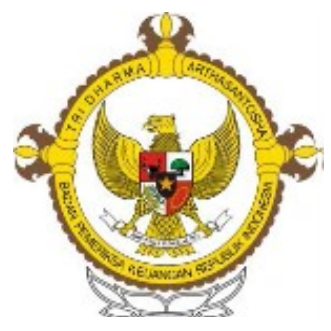

JURNAL

TATA KELOLA \& AKUNTABILITAS KEUANGAN NEGARA

Volume 5, Number 1, Jan-Jun 2019, 37-56

e-ISSN 2549-452X

p-ISSN 2460-3937

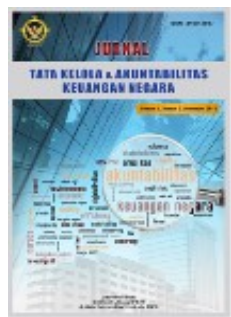

\title{
CAN THE INTERNAL CONTROL SYSTEM REDUCE FRAUDULENT USE OF VILLAGE FUNDS IN ADVERSE SELECTION CONDITION?
}

\author{
Theresia Febiengry Sitanala \\ Universitas Pattimura \\ feisya_1011@yahoo.ca
}

\begin{abstract}
In recent years, corruption cases at the village level have been in the public spotlight. This was evidenced through around 154 corruption cases at the village level involving 112 village heads, 32 village officials and 3 village heads. This corruption case resulted in the state experiencing a loss of 47.56 billion rupiah during 2015-2017. This case is carried out through various modes such as the practice of budget abuse, fictitious reports, fictitious activities/projects, and budget bubbles. These various modes occur because the internal control system is ineffective, so it provides an opportunity for actors to act opportunistically. The goal is to maximize his personal interests as agents rather than the interests of the community as principals. This opportunistic behavior is caused by the existence of information asymmetry. Information asymmetry creates conditions for obtaining information that is not aligned between the village head as an agent and the community as the principal, so that the emergence of adverse selection. This study aims to examine the effect of the internal control system on fraudulent use of village funds in agency conflict conditions through adverse selection. This study used the laboratory experiment method with the subject being Accounting Student at Pattimura University Ambon. The data analysis technique uses Two-Way ANOVA with a 2x2 factorial experimental design. The results of the study show that (1) adverse selection conditions affect the relationship between the internal control system and fraudulent use of village funds, (2) the internal control system that does not effectively affect fraudulent use of village funds under adverse selection is compared to no adverse selection (3) adverse selection conditions do not affect fraudulent use of village funds when the internal control system is effective, and (4) in the absence of adverse selection, an effective internal control system will reduce fraudulent use of village funds compared to ineffective internal control systems.
\end{abstract}

\section{KEYWORDS:}

Internal control system; adverse selection; village funds 


\section{INTRODUCTION}

One of the Indonesian government programs is to develop Indonesia from the periphery by strengthening regions and villages within the framework of a unitary state. To achieve this goal, the government needs a budget allocation of village funds. Village Funds is one form of implementation of Law Number 6 of 2014. Specifically, the legislation governing village funds is Government Regulation Number 8 of 2016 concerning the Second Amendment to Government Regulation Number 60 of 2014. Subsequently, the technical regulations for village funds are Minister of Finance Regulation Number 257/ PMK.07 /2015 concerning Procedures for Delays and/or Deductions of Balancing Funds for regions that do not meet Village Fund Allocation, Minister of Finance Regulation Number 49/PMK.07/2016 concerning Procedures for Allocation, Distribution, Use, Monitoring and Evaluation of Village Funds, as well as Minister of Finance Regulation Number 50/PMK.07/2017 concerning Management of Transfers to Regions and Village Funds as amended by PMK Number 112/PMK.07/2017. The two biggest sources of village income are the State Budget through the Village Fund and the Regional Expenditure Budget through the Village Funds Allocation. Table 1 is showing the budget allocation for village funds during 2015-2017.

Table 1. Village Fund Budget Allocation

\begin{tabular}{ccc}
\hline Years & $\begin{array}{c}\text { Budget Allocation } \\
\text { (trillion rupiah) }\end{array}$ & $\begin{array}{c}\text { Number of } \\
\text { Villages }\end{array}$ \\
\hline 2015 & 20,76 & 74,093 \\
\hline 2016 & 46,98 & 74,754 \\
\hline 2017 & 60,00 & 74,954 \\
\hline
\end{tabular}

Source: ICW (2018)

Table 1 shows that during 2015-2017, village funds allocations increased significantly. Increasing the allocation of village funds provides an opportunity for actors to misuse the village funds budget. According to the Corruption Eradication Commission (KPK), there are five potential corruption-prone processes, namely (1) the planning process (the existence of elite capture); (2) the implementation process (the potential for nepotism and non-transparency); (3) the process of procurement of goods and services the context of distribution and management of village funds (the existence of potential mark-up, engineering, and nontransparency); (4) the accountability process twice (the existence of potential fictitious reports); and (5) the monitoring and evaluation process (only formalities, administrative and late corruption detection) (ICW, 2018). Furthermore, ICW (2018) explained that corruption in the village, mainly concerning village budgets and is one of the fundamental problems. This problem occurs because of large budget management, but its implementation at the village level is not accompanied by the principles of transparency, participation, and accountability in village political, development and financial governance.

Table 2 shows that during 2015-2017 the number of corruption cases that occurred at the village level experienced a significant increase. The number of corruption cases that occurred in 2015 were 17 cases. Furthermore, in 2016 the number of corruption cases has increased, so that there are 41 cases. Finally, in 2017 this number experienced twice the increase in the number of corruption cases in 2016, which amounted

Tabel 2. Corruption Cases at the Village Level

\begin{tabular}{cccc}
\hline Years & $\begin{array}{c}\text { Number } \\
\text { of Cases }\end{array}$ & $\begin{array}{c}\text { Number of } \\
\text { Involvement of } \\
\text { Village Heads }\end{array}$ & $\begin{array}{c}\text { Value of } \\
\text { State Losses } \\
\text { (trilion rupiah) }\end{array}$ \\
\hline 2015 & 17 & 15 & 9.12 \\
\hline 2016 & 41 & 32 & 8.33 \\
\hline 2017 & 96 & 65 & 30.11 \\
\hline Total & 154 & 112 & 47.56 \\
\hline
\end{tabular}

Source: ICW (2018) 
to 96 cases. Thus, during the last three years (2015-2017), the total number of corruption cases in the village reached 154 cases. ICW (2018) explained that out of 154 total corruption cases, 127 cases were cases with the object of the village budget such as corruption in the village funds, allocation of village funds, village treasuries, and others. Meanwhile, 27 cases with village non-budget objects such as illegal levies were carried out by village officials. Based on table 2, the researcher concludes that the village head is an important actor involved in the abuse of village funds. During the last three years (2015-2017), the number of village head involvement in corruption cases continued to increase. In addition, corruption at the village level does not only involve the village head. However, this corruption involved 32 village officials and 3 people who were village head family (ICW, 2018). As a result, the country experienced total losses over the past three years amounting to 47.56 billion rupiah, equivalent to the basic allocation of APBN funds for 77 villages.

Cases of corruption at the village level have various modes such as, the practice of misuse of the budget as many as 51 cases, embezzlement of 32 cases, fictitious reports with 17 cases, fictitious activities/projects of 15 cases, and inflation of 14 cases (ICW, 2018). Furthermore, ICW (2018) explained that from the aspect of law enforcement, all law enforcement officials were known to have handled corruption cases that occurred in the village. The most cases of corruption were handled by the Republic of Indonesia National Police with a total of 81 cases. Meanwhile, the Indonesian Prosecutor's Office handled 72 cases, and 1 case involving the District Head of Pamekasan was handled by KPK. Factors that caused corruption at the village level were (1) the lack of community involvement in the village budget planning and supervision process; (2) the inadequacy of village institutions such as the
Village Consultative Body (BPD); (3) limited village head competency; and (4) the high cost of political village head elections (ICW, 2018). In other words, the fundamental factor causing corruption at the village level is an ineffective internal control system.

The internal control system is a method used to protect or protect assets, produce reliable information, improve efficiency, and protect management policies (Krismadji, 2008). Meanwhile Boynton, Johnson and Kell (2002) explain that the internal control system is a process carried out by the board of directors, management, and other personnel in an entity that has been designed and compiled to convince users in achieving goals including (a) reliability in making financial reporting, (b) compliance with applicable laws and regulations, and (c) achieving operational effectiveness and efficiency. Furthermore, Boynton et al. (2002) explain that compliance with regulations in making accountability reports or fraud levels has a relationship with the implementation of an internal control system. An effective internal control system can affect the quality of transaction testing, detect fraud, and improve the effectiveness and efficiency of organizational activities. The more effective the internal control system is designed in accordance with organizational goals, the more effective the implementation is to detect fraud. Lane and O'Connell (2009) explain that implementing an effective internal control system through the main focus of the system can reduce fraud in the organization.

Tehupuring and Lingga (2017) explain that the higher the internal control system, the lower accounting fraud. Conversely, the lower the internal control system, the higher accounting fraud. Accounting fraud is an unethical behavior that is not only detrimental to the person. However, this action can be detrimental to society in general. Thoyibatun 
(2009) explains that the suitability of the internal control system with organizational goals can reduce unethical behavior and accounting fraud tendencies. Accounting fraud, especially fraudulent use of village funds is motivated by opportunities. Wanjohi (2014) explains that fraud developed rapidly due to the availability of opportunities to commit fraud including, ineffective internal control systems. Wainaina (2011) explains that the evaluation of the functions of internal control in addition to prevention and detection of fraud must reflect the strength of the accounting environment fundamentally in an organization and the accuracy of financial and operational records. Organizations that are not focused on implementing an internal control system or an ineffective internal control system will lead to failure for the organization (Tunji, 2013; Hartman, 2014).

Ineffective internal control systems provide opportunities for actors to act opportunistically. This opportunist action is carried out by the actor with the aim of maximizing his personal interests as an agent rather than the interests of the community as principal. The conflict of interest between the actor as an agent and the community as principal is due to the existence of information asymmetry. Information asymmetry is a condition of unbalanced information between agents who are responsible for managing village organizations with stakeholders, namely, the community as principals. The existence of this information asymmetry causes the emergence of the term adverse selection. Scott (2015) explained that adverse selection occurs when the agent as the party managing the organization knows the prospects of the organization more than the principal. This adverse selection condition is then used by the agent to fulfill its interests compared to the interests of the principal. The motivation for this action is because of three basic human assumptions, namely humans are essentially selfish, humans have limited thinking about future perceptions, and humans always avoid risk (Eisenhardt, 1989).

The findings of Muna and Harris (2018); Lestari and Supadmi (2017); Randiza, Kamaliah and Anisma (2016); also Triasmara and Anna (2014) show that the internal control system can reduce accounting fraud tendencies, and information asymmetry can increase the tendency of accounting fraud. Meanwhile, Nurhayati and Muniarty (2018) also Frilia, Agusti and Savitri (2015) show that the internal control system cannot reduce the tendency of accounting fraud, and information asymmetry can increase the tendency for accounting fraud.

Setiawan, Adiputra and Yuniarta (2015) show that the internal control system had a negative and significant effect on fraud and information asymmetry had no significant effect on fraud. Furthermore, Gusmaini, Fauziati and Yulistia (2014) also Ahriati, Basuki and Widiastuti (2015) show that the internal control system and information assymetry had no significant effect on accounting fraud tendencies. Accounting fraud is caused by a lack of individual morality, so that behaving unethically to fulfill its interests. Puspasari and Suwardi (2012) explain that the interaction between individual morality and internal control can influence the tendency of accounting fraud. An effective internal control system can suppress the opportunistic behavior of the village head as an agent, both in the absence of adverse selection and in the condition of adverse selection. Agencies as the party managing the organization will see the internal control system as a system that can bind individual behavior not to commit fraud in embezzling village funds because it will be easily detected.

An effective internal control systems can be 
identified through (1) village officials do not carry out the role of multiple tasks; (2) transactions are recorded accurately; (3) there is authorization of proof of transactions bt the authorities; (4) periodic inspection of asset inventories; (5) accounting information systems are able to represent all transactions that occur without skipping other transactions; and (6) accountability and transparency in budget reporting and realization of village funds. Dewi and Ratnadi (2017) explain that if an organization's internal control system is weak, then the possibility of mistakes and fraud will increase. Conversely, if the internal control system of an organization is strong, then the possibility of an error or fraud can be minimized. Based on this description, the purpose of this study is to examine the effect of the internal control system on fraudulent use of village funds in adverse selection conditions.

\section{Internal Control Systems, Adverse Se- lection, and Fraudulent Use of Village Funds}

The Indonesian Institute of Accountants (IAI, 2012) defines accounting fraud as (1) misstatements arising from fraud in financial reporting, namely, misstatement or deliberate omission of amounts or disclosures in financial statements to deceive users of financial statements, (2) misstatements arising from improper treatment of assets (often referred to as misuse or embezzlement) relating to the theft of assets of an entity which results in financial statements not being presented in accordance with the General Applicable Accounting Principles (PABU) in Indonesia. Based on fraud triangle theory, the causes of fraud are pressure, opportunity, and rationalization. Pressure relates to the need or incentive to commit fraud, for example the need for lifestyle, economic needs, external pressure and others. Opportunities relate to situations or conditions that allow fraud to occur, for example an ineffective internal control system or abuse of authority. Rationalization relates to attitudes or ethics that allow individuals to commit fraud and rationalize fraudulent actions as reasonable actions. These three factors are determinants of individuals committing fraud (Tehupuring \& Lingga, 2017).

Albrecht and Albrecht (2004) state that fraud occurs because individuals violate ethics, honesty, and responsibility. These three elements indicate that individuals have problems in applying moral values. Individuals who have good morals will be responsible for carrying out their duties and functions to achieve organizational goals. Conversely, individuals who have low moral values will use opportunities and rationalizations to commit fraud. Moreover, supported by the implementation of an ineffective internal control system, individuals will see this condition as an opportunity to commit fraud. Krismadji (2008) states that the internal control system is a method used to safeguard or protect assets, produce reliable information, improve efficiency and to protect management policies. Organizations must have an internal control system such as a control environment, risk management by management, accounting information and communication systems, and control and monitoring activities (Arens \& Loebecke, 1996).

Boynton et al. (2002) explain that compliance with regulations in making accountability reports or fraud levels has a relationship with the implementation of an internal control system. Effective implementation of internal control systems will improve the quality of transaction testing, detect fraud, and achieve organizational effectiveness and efficiency. The internal control system designed in accordance with the organization's objectives will be effective if the system is easy to implement and the executor has good moral responsibility. 
An ineffective internal control system will provide opportunities for individuals to behave opportunistically in increasing their prosperity. This opportunist action is carried out by individuals with the aim of maximizing their personal interests as agents rather than the interests of the community as principals. Conflicts of interest between individuals (village heads) as agents and the community as principals are due to information asymmetry. This information asymmetry occurs because of the imbalance of information between agents who are responsible for managing village organizations with stakeholders, namely, the community as principals. This conference causes the term adverse selection to appear. Scott (2015) explains that adverse selection occurs when the agent as the party managing the organization knows the prospects of the organization more than the principal. This adverse selection condition is then used by agents for opportunistic behavior in meeting their interests compared to the interests of principals. Finally, this behavior results in fraudulent use of village funds and reduces the welfare of a just and prosperous community.

Results from Muna and Harris (2018), also Randiza et al. (2016) prove that the internal control system can reduce accounting fraud tendency, and information asymmetry can increase the tendency of accounting fraud. Meanwhile, the findings of Nurhayati and Muniarty (2018) show that the internal control system cannot reduce the tendency of accounting fraud, and information asymmetry can increase the tendency of accounting fraud. Accounting fraud occurs showing that individuals have low morals, so behaving unethically to fulfill their interests. Puspasari and Suwardi (2012) explain that the interaction between individual morality and internal control can influence the tendency of accounting fraud. Based on the description, the hypothesis proposed is as follows.
H1 : Adverse selection conditions affect the relationship between the internal control system and fraudulent use of village funds.

\section{Internal Control Systems Are Not Ef- fective, Adverse Selection, and Fraud- ulent Use of Village Funds}

Jensen and Meckling (1976) explain that agency conflict occurs because of the information asymmetry between agents and principals. Agencies as the party managing the organization have more comprehensive information than the principal. In the context of the village government, agents are village heads and their ranks. Meanwhile, the principal is a village community. The village head as an agent will use this comprehensive information as important information in maximizing his interests. Meanwhile, the community as principal expects the village head to act in accordance with the interests of the community, namely, improving the welfare of a just and prosperous society. Through village funds, the village head is responsible for increasing village prosperity. Village funds are funds sourced from the State Expenditures Budget allocated to villages and transferred through the District/City Regional Expenditure Budget with the aim of carrying out development and empowerment of village communities. The specific objectives are to improve public services in the village, alleviate poverty, promote the village economy, overcome inter-village development gaps, and strengthen village communities as the subject of development (Ministry of Finance, 2018).

The responsibility of the village head to improve community welfare is often not done well. This can occur because of pressure, opportunity, and rationalization. These three factors are the motives of the village head to commit fraud in the use of village funds. The need or incentive to commit fraud, for exam- 
ple lifestyle needs, economic needs, the presence of external pressure are conceptualized as pressure. Situations or conditions that allow fraud to occur, such as ineffective internal control systems or abuse of authority are conceptualized as opportunities, and attitudes or ethics that allow individuals to commit fraud and rationalize fraudulent actions as reasonable actions are conceptualized as rationalization. These three motives when not supported by an effective internal control system will result in fraudulent use of village funds. An ineffective internal control system will provide opportunities for individuals to behave opportunistically in increasing their prosperity. This condition can occur because information about village organizations is better known by the village head than by the village community, so that when the ineffective internal control system is supported by ownership of more comprehensive information from the village head resulting in fraudulent use of village funds.

H2 : The internal control system that is not effective in causing fraud in the use of village funds under conditions is adverse selection compared to no adverse selection

\section{Effective Internal Control Systems, Adverse Selection, and Fraudulent Use of Village Funds}

In the Fraud Triangle Theory, individuals commit fraud caused by three important factors, namely, pressure, opportunity, and rationalization. Pressure involves an individual situation that creates more benefits such as gaining clarity in the form of bribery and can arise from work problems and unrealistic performance targets; the opportunity to commit fraud is possible if individuals have access to assets and information that triggers individuals to commit fraud; and rationalization involves individuals to align their behavior with ideas that are generally accepted through politeness and trust (Tehupuring \& Lingga, 2017). According to Ruankaew (2013), these three factors are the cause of individuals cheating. Therefore, fraud can occur when there are three elements.

Another important motivation that influences individuals to commit fraud is because of the agency conflict proposed by Jensen and Meckling (1976). Agency conflicts occur in village organizations because the village head as an agent has more information regarding the performance of village organizations than village communities as principals. As a result, this information was used as the village head as an opportunity to fulfill his interests, namely, increasing his welfare, thereby reducing the welfare of the people who were just and prosperous. To reduce the occurrence of these conditions, it is necessary to implement an effective internal control system. When the internal control system is effectively implemented, the village head who has more information related to the performance of the village organization or the information is known by the community does not affect the village head to commit fraudulent use of village funds.

The important reason is an effective internal control system that has been designed in accordance with the organization's objectives and effectively implemented, including (1) village officials do not perform the role of multiple tasks; (2) transactions are recorded accurately; (3) there is authorization to proof of transactions by parties authority; (4) periodic inspection of asset inventories; (5) accounting information systems capable of representing all transactions that occur without missing other transactions; and (6) accountability and transparency in budget reporting and realization of village funds will close the opportunity for village heads to act opportunistically in fraudulent use of village funds. Lane and O'Connell (2009) explain that implementing an effective internal 
control system through the main focus of the system can reduce fraud in the organization. Based on the description, the research hypothesis is as follows.

H3 : The adverse selection condition does not affect fraudulent use of village funds when the internal control system is effective

\section{Internal Control System, No Adverse Selection, and Fraudulent Use of Vil- lage Funds}

Krismadji (2008) explains that the internal control system is a method used to protect or protect assets, produce reliable information, improve efficiency and protect management policies. Meanwhile, Boynton et al. (2002) explain that the internal control system is a process carried out by the board of directors, management, and other personnel in an entity that has been designed and compiled to convince users in achieving objectives including reliability in making financial reporting, compliance with applicable laws and regulations, and achieving operational effectiveness and efficiency. The effectiveness and efficiency of organizational activities, the quality of transaction testing, and fraud detection can be reduced when the internal control system is implemented effectively.

Lane and O'Connell (2009) explain that implementing an effective internal control system through the main focus of the system can reduce fraud in the organization. Guided by Lane and O'Connell (2009), the strength of the implementation of the internal control system when applied effectively when compared to internal control systems is not implemented effectively. An effective internal control system will reduce fraud committed by the village head when information related to the performance of village organizations is known by the village community. Although the village head has the authority to carry out village government activities, and has the potential to use his authority for personal interests, but if supported by an effective internal control system, it will reduce the actions of the village head to abuse his authority. Based on the description, the research hypothesis is as follows.

$\mathrm{H}_{4}$ : In conditions where there is no adverse selection, an effective internal control system will reduce fraudulent use of village funds compared to the ineffective internal control system

\section{RESEARCH METHODS}

\section{Experimental Method and Research Design}

This study uses an experimental method to explain the phenomena that occur. Nahartyo (2013) states that the experimental method is research design to investigate a phenomenon by manipulating a condition or condition through a particular procedure and then observing the results of the engineering and interpreting it. This section of research includes manipulation of the independent variables and observations of the effects of these variables on the dependent variable (Campbell \& Stanley, 1966). The researcher manipulated the treatment through the case of the tender project for the construction of bridges in a village with the condition that the internal control system was effective versus ineffective, and there was an adverse selection versus no adverse selection.

The type of experiment used in this study is laboratory experiments. Nahartyo (2013) states that in a laboratory experiment, researchers manipulate the independent variables and control other variables that have the potential to influence the dependent variable but are not relevant to the research objectives. The laboratory experiment method is 
organized in an artificial environment where control and manipulation are given to prove a causal relationship between the variables studied (Nahartyo, 2012). The artificial environment was carried out by researchers by choosing the subject of the University of Pattimura Ambon (UNPATTY) accounting student who was given an engineering role as the village head. To find out the success of the role of the subject as the village head, the researcher checks the manipulation. Therefore, researchers will only use subject data that has passed the manipulation check. The aim is to improve the accuracy and quality of research results.

The important reason for researchers to use student subjects in laboratory experimental research rather than village heads is to eliminate bias such as psychological pressure because the organizational environment and position in the village government structure have a tendency not to respond to the actual conditions. This can happen because this research is related to ethics, morals, and the responsibility of the village head which is quite sensitive about fraudulent use of village funds. Therefore, laboratory experimental methods are more suitable in explaining the phenomena that occur and can reduce the good bias, bias due to pressure or bias because the variables outside the research model.

The researcher used the $2 \times 2$ factorial ANOVA experimental design to examine the effect of the internal control system on fraudulent use of village funds in adverse selection conditions. Puspasari and Suwardi (2012) have examined the effect of individual morality and internal control on the tendency of accounting fraud: experimental studies in the context of local government. Tehupuring and Lingga (2017) tested the internal control system as a predictor of accounting fraud in local government. Furthermore, Narsa and Supriyadi (2017) examined the role of the com- pany's code of ethics in mitigating managerial escalation behavior framed agency theory. Therefore, the researcher adapted and modified the scenario or experimental module according to the context of this study by referring to the three studies. Furthermore, the researcher conducted a discussion on the validity of the research module with several lecturers who were relevant to the topic of this research. Nahartyo and Utami (2015) stated that this discussion was important to determine validity, experimental procedures, and case material with the aim of obtaining perfection of experimental design. Table 3 shows that researchers divided subjects into four groups. The aim is to observe the tendency for fraud to use village funds. Group 1: effective internal control system with adverse selection conditions; Group 2: the internal control system is not effective with adverse selection conditions; Group 3: the internal control system is ineffective with no adverse selection conditions; and Group 4: the internal control system is ineffective with no adverse selection conditions.

Table 3. Factorial $2 \times 2$ ANOVA Experiment Design

\begin{tabular}{ccc}
\hline $\begin{array}{c}\text { Internal } \\
\text { Control System }\end{array}$ & \multicolumn{2}{c}{ Adverse Selection } \\
& YES & NO \\
\hline Effective & Group 1 & Group 3 \\
\hline Ineffective & Group 2 & Group 4 \\
\hline
\end{tabular}

\section{Operational Definitions and Variable Measurements}

This study uses independent variables and the dependent variable in examining the effect of the internal control system on fraudulent use of village funds in adverse selection conditions. The independent variable in this study is the internal control system (effective and ineffective) and adverse selection (existing and non-existent). Meanwhile, the dependent variable is fraudulent use of village funds. The following is an explana- 
tion of operational definitions and measurement of research variables.

The internal control system is a system consisting of various elements and is not limited to accounting and finance, but includes budget control, standard costs, employee training programs and so on (Tehupuring \& Lingga, 2017). The measurement of the internal control system uses two levels, namely, the level of internal control is effective and ineffective. The following is a brief explanation of the level of effective and ineffective internal control systems.

The level of the internal control system effectively occurs when the village government has implemented rules regarding behavior and prioritizes disciplinary action on irregularities or violations of policies and procedures. Every transaction is always recorded on time, the transaction authorization and supporting evidence are always carefully considered. Supervision and physical inspection are always carried out regularly, there are no employees who work concurrently, and evaluation of operational activities to assess the degree of asset security is always carried out periodically. Finally, the Village Consultative Body (BPD) has effectively overseen the implementation of village governance in ensuring compliance with policies in accordance with applicable procedures.

The level of the internal control system is ineffective when the village government has implemented rules regarding behavior and prioritizes disciplinary action on irregularities or violations of policies and procedures. However, the implementation of these rules has not been effective. The transaction date is often not in accordance with the transaction that should have occurred. In addition, often the authorization and supporting evidence are not in accordance with applicable regulations. Supervision and physical inspection are only carried out occasionally, there are some employees who are concurrently assigned, and evaluation of operational activities to assess the degree of asset security is not always done. The Village Consultative Body (BPD) is less effective in overseeing the implementation of village governance in ensuring compliance with policies in accordance with applicable procedures.

Adverse selection is a condition that occurs when the agent as the party managing the organization knows the prospects of the organization better than the principal (Scott, 2015). Agents in this study are village heads and principals are village communities. As a result, information asymmetry emerged between the village head and the community, so the village head benefited from this information and neglected the welfare of the village community. The measurement of adverse selection uses two conditions, namely, conditions are adverse selection and there is no adverse selection. The brief explanation of the condition of adverse selection and no adverse selection are:

1. An adverse selection occurs when information about poor performance is only known by budget users (village head) and is not known by other parties outside the organization.

2. No adverse selection conditions occur when information about poor performance is widely known by outsiders, especially the village community.

The fraudulent use of village funds is the act of the village head using village funds to fulfill his interests. To measure fraudulent use of village funds, the subject is given a scenario or case of tender for a bridge construction project. The form of the subject's decision as the village head to approve or disagree with the offer of his old friend's company to win the tender for the bridge construction project using 10 points Likert scale. The scale is divided at the midpoint, that is, between 5 and 
6. Subjects who choose the Likert 1-5 scale indicate that the subject decides not to accept the offer of his old friend's company. That is, the more the subject decides to choose scale 1 shows that the subject is more certain not to approve the offer of the old friend company to win the tender for the bridge construction project. Conversely, the subject who chose 1-6 scale indicated that the subject decided to accept the offer of his old friend's company. That is, the more the subject decides to choose a scale of 10 indicating that the subject is more certain to approve the offer of the old friend's company to win the tender for the bridge construction project.

\section{Experimental Procedure}

This laboratory experiment research is carried out through a series of procedures that will be carried out by the subject. Subjects are given assignments through the division of experimental modules but are not allowed to work before all subjects receive the experimental module. After all the subjects received the experimental module, the researcher gave a brief briefing on the assignment to be given to the subject.

In the experimental module, subjects generally act as village heads in a district. The subject is given information that one of the village work programs is to build bridges and will go through a tender process. One of the tender companies was an old friend of the village head and he promised that if the company won the tender, it would be given a $25 \%$ discount from the project nominal to you as the village head and the party who helped his victory. In total there are four groups, each of which will receive an experimental module that varies according to the treatment given.

Subjects for Group 1 will be given an experimental module by treating the effective internal control system with adverse selection conditions; Group 2 by treating the ineffective internal control system with adverse selection conditions; Group 3 with an ineffective inter- nal control system treatment with no adverse selection conditions; and Group 4 by treating the internal control system ineffectively with no adverse selection conditions.

At the end of the assignment, subjects were asked to act as village heads who had to make a decision to accept or reject the offer of old friends through the response of subjects on a scale of 1-10. After that, the subject completes the procedure for manipulating checks through two questions. The first question about the effectiveness of the internal control system is through employees who double the task or not depending on the treatment received by the subject, and the second question about the responsibility of the subject as the party conducting the audit or as a user of the village budget.

\section{Research Subject}

This research was conducted at Pattimura University Ambon by using laboratory experimental methods. This laboratory experiment method is carried out through subjects who act as village heads to reduce response bias. This subject is the third person used to reduce bias because the subject cannot show the actual response when faced with sensitive issues. The scenario in this experimental module uses the context of the third person such as the research of Rest (1986), Arnold and Ponemon (1991), Bernardi and Guotil (2008), also Liyanarachi and Newdick (2009) for ethical studies.

The researcher chose accounting students at Pattimura University Ambon with several main reasons, namely (1) accounting students were equipped with a comprehensive understanding of ethical issues. For this reason, accounting students must have passed the business and professional ethics courses and auditing; (2) Pattimura Ambon Ambon accounting students are still rarely used as subjects in experimental research, so as to improve the quality of student responses 
compared to students who have often been used as subjects in experimental research; and (3) the topics studied relate to issues of ethics, morals, and sensitive responsibilities if done directly to the village head, so that accounting students are more suitable to be subjected to obtaining the actual response without psychological pressure.

This study used 80 subjects divided into four groups. However, this study only obtained 51 subjects who had passed the manipulation check. The 51 subjects consisted of four groups. Group 1 is 16 subjects; group 2 is 12 subjects; group 3 is 10 subjects; and group 4 numbered 13 subjects. Nahartyo (2012) states that the total subject for each group is at least 10 subjects. Therefore, this study fulfilled the requirements for the minimum number of subjects in one group. Manipulation checks were carried out with the aim of increasing the accuracy and quality of the data on the subject's response because the subject had succeeded in receiving the treatment of the condition of the role of the village head given by the researcher.

\section{Data Analysis Technique}

This study uses Analysis of Variances (ANOVA) to test the research hypothesis. The use of ANOVA requires researchers to test several assumptions namely normality and homogeneity. The normality test was carried out through a one-sample test of Kolmogorov Smirnov with provisions, namely, if sig. > 0.05, then the residual is normally distributed. Meanwhile, the homogeneity test uses Levene's test with the provision that, if sig. > 0.05, then the residual is homogeneous. After this research model fulfills both assumptions, the researcher conducted a two -way ANOVA test and post-hoc test using a tukey test to determine the significant difference in group averages. Thus, the researcher can conclude the average comparison of each group and answer the research hypothesis (Ghozali, 2006).

\section{RESULTS AND DISCUSSION}

This study uses two manipulation check questions for all scenarios given to the subject. The results of the subject's response to the two manipulation check questions were used by the researcher to determine the seriousness of the subject in the experiment. That is, if the subject responds to a question by choosing the right option, the subject has understood his role as the village head, thereby reducing the bias of the subject's decision in responding to this research question. Therefore, the subject whose data has passed the manipulation check will be used to test the research hypothesis. The results of

Table 4. Manipulation Check Results

\begin{tabular}{cccc}
\hline $\begin{array}{c}\text { Group } \\
\text { Research }\end{array}$ & $\begin{array}{c}\text { Number of } \\
\text { Subjects }\end{array}$ & $\begin{array}{c}\text { Subjects Failed } \\
\text { to Answer } \\
\text { Questions }\end{array}$ & $\begin{array}{c}\text { Final } \\
\text { Subject }\end{array}$ \\
\hline Group 1 & 20 & 4 & 16 \\
\hline Group 2 & 20 & 8 & 12 \\
\hline Group 3 & 20 & 10 & 10 \\
\hline Group 4 & 20 & 7 & 13 \\
\hline
\end{tabular}

the manipulation check can be seen in table 4 .

Table 4 shows that this study divided subjects into four groups. The four groups were given different treatments with a total of 80 groups with 20 subjects each. However, the results of the manipulation check show that group 1 only passed a manipulation check totaling 16 subjects. Meanwhile, 4 subjects did not pass the manipulation check. Group 2 only passes the manipulation check for 12 subjects. Meanwhile, 8 subjects did not pass the manipulation check. Group 3 only passed the manipulation check for 10 subjects and 10 subjects did not pass the manipulation check. Group 4 only passed the manipulation check totaling 13 subjects and did not pass manipulation checks totaling 7 subjects. Based on the description, then the subject in group 1 has the most final subject. Mean- 
while, subjects in group 3 who had the least final subject.

Table 5 showing the descriptive statistics of the subjects used in this study. The researcher conducted a randomization test to find out the distribution of each subject evenly in each group. Based on the results of the randomization test, the researchers concluded that the gender of the subject of this study had a test value $\mathrm{F}=0.261$, sig. 0.611 ; and age has a test value $F=1,145$, sig. 0.290. Thus, there were no significant differences between male and female treatment groups, as well as treatment groups aged 18-20 and ages 21-23. Therefore, the research subjects were evenly distributed and there were no confounding variables in this research model.

The assumption that must be fulfilled before carrying out the ANOVA test is the assumption of normality and homogeneity. The results of testing for normality using one- sample Kolmogorov Smirnov show the value of sig. 0.329>0.05. The results of this normality test prove that the research model has a normally distributed residual, so this research model has met the assumptions of normality. Next, the researcher conducted a homogeneity test through Levene's test. The results of testing homogeneity through leven's test show the value of sig. 0.077>0.05. The results of this homogeneity test prove that the research model has a residual variance that is homogeneous, so that this research model has met the assumption of homogeneity.

This study used a 2x2 factorial ANOVA test, descriptive response decision statistical test, and post-hoc test through the Tukey test to test the research hypothesis. Table 6 showing the results of the $2 \times 2$ factorial ANOVA test.

Testing the first hypothesis (H1), namely, adverse selection conditions affect the rela-

Table 5. Subject Descriptive Statistics

\begin{tabular}{|c|c|c|c|c|c|}
\hline Variable & Treatment Group & Category & $\mathrm{N}$ & Percentage & Total \\
\hline \multirow{8}{*}{ Gender } & \multirow{2}{*}{ Group 1} & Male & 7 & $44 \%$ & \multirow{8}{*}{$\begin{array}{c}\text { Male }=(43 \%) \\
\text { Female }=(57 \%)\end{array}$} \\
\hline & & Female & 9 & $56 \%$ & \\
\hline & \multirow{2}{*}{ Group 2} & Male & 5 & $42 \%$ & \\
\hline & & Female & 7 & $58 \%$ & \\
\hline & \multirow{2}{*}{ Group 3} & Male & 4 & $40 \%$ & \\
\hline & & Female & 6 & $60 \%$ & \\
\hline & \multirow{2}{*}{ Group 4} & Male & 6 & $46 \%$ & \\
\hline & & Female & 7 & $54 \%$ & \\
\hline \multirow{8}{*}{ Age } & \multirow{2}{*}{ Group 1} & $18-20$ & 7 & $44 \%$ & \multirow{8}{*}{$\begin{array}{l}18-20 \text { year }=(52 \%) \\
21-23 \text { year }=(48 \%)\end{array}$} \\
\hline & & $21-23$ & 9 & $56 \%$ & \\
\hline & \multirow{2}{*}{ Group 2} & $18-20$ & 5 & $42 \%$ & \\
\hline & & $21-23$ & 7 & $58 \%$ & \\
\hline & \multirow{2}{*}{ Group 3} & $18-20$ & 6 & $60 \%$ & \\
\hline & & $21-23$ & 4 & $40 \%$ & \\
\hline & \multirow{2}{*}{ Group 4} & $18-20$ & 8 & $62 \%$ & \\
\hline & & $21-23$ & 5 & $38 \%$ & \\
\hline
\end{tabular}


Jurnal Tata Kelola \& Akuntabilitas Keuangan Negara, Vol. 5, No.1, 2019, 37-56

Table 6. Factorial $2 \times 2$ ANOVA Test Results

\begin{tabular}{lcccc}
\hline \multicolumn{1}{c}{ Source } & Df & Mean Square & F & Sig. \\
\hline Corrected Model & 3 & 40.758 & 6.885 & $0.001^{* * *}$ \\
\hline Intercept & 1 & 1891.672 & 319.545 & $0.000^{* * *}$ \\
\hline SPI & 1 & 27.251 & 4.603 & $0.037^{* *}$ \\
\hline ADS & 1 & 24.856 & 4.199 & $0.046^{* *}$ \\
\hline SPI X ADS & 1 & 70.123 & 11.845 & $0.001^{* * *}$ \\
\hline Error & 47 & 5.920 & & \\
\hline Total & 51 & & & \\
\hline Corrected Total & 50 & & & \\
\hline $\mathrm{R}^{2}=0.305$ & & & \\
Adjusted $\mathrm{R}^{2}=0.261$ & & & \\
Notes: $* * *$ significance at $1 \% ; *$ significance at $5 \%$ & & & \\
\hline
\end{tabular}

tionship between the internal control system and fraudulent use of village funds. Based on table 8 , the test results show that the interaction between the internal control system and adverse selection has a value of $\mathrm{F}=$ 11,845 , and sig. 0.001 at $1 \%$ significance level. The findings of this study indicate that the strength of the influence of these interactions proves the existence of interdependencies between the internal control system and adverse selection. Thus, the first hypothesis (H1) is supported.

Changes in adverse selection conditions (adverse selection and no adverse selection) will affect changes in agent behavior in committing fraudulent use of village funds depending on the effective or ineffective internal control system. Tehupuring and Lingga (2017) explains that the higher the internal control system, the lower accounting fraud. Conversely, the lower the internal control system, the higher accounting fraud. An ineffective internal control system provides an opportunity for the village head as an agent to act opportunistically. This opportunist action is carried out by the agent with the aim of maximizing his personal interests as agents rather than the interests of the community as principals.
The conflict of interest between the village head as an agent and the community as principal is due to the existence of information asymmetry. Information asymmetry is a condition of unbalanced information between agents who are responsible for managing village organizations with stakeholders, namely, the community as principals. The existence of this information asymmetry causes the emergence of the term adverse selection. Scott (2015) explained that adverse selection occurs when the agent as the party managing the organization knows the prospects of the organization more than the principal. This adverse selection condition is then used by the agent to fulfill its interests compared to the interests of the principal. The motivation for this action is because of three basic human assumptions (Eisenhardt, 1989).

To test hypotheses 2, 3, and 4, the researchers used the descriptive statistics of decision response test and the Tukey test. Table 7 shows the results of testing the descriptive statistics of decision response test and table 8 shows the results of post-hoc tests through the Tukey test. The second hypothesis testing (H2), namely, that the internal control system that is not effective in in- 
Table 7. Descriptive Statistics of Decision Response

\begin{tabular}{|c|c|c|c|}
\hline \multirow{2}{*}{ Internal Control System } & \multicolumn{2}{|c|}{ Adverse Selection } & \multirow{2}{*}{ Total } \\
\hline & YES & NO & \\
\hline \multirow{4}{*}{ Effective } & Group 1 & Group 3 & \multirow{4}{*}{$\begin{array}{c}(\mathrm{N}=26) \\
(\text { Mean=6.80) } \\
(\text { Std. }=2.15)\end{array}$} \\
\hline & $(N=16)$ & $(\mathrm{N}=10)$ & \\
\hline & (Mean=6.43) & (Mean=7.40) & \\
\hline & $(S t d .=2.27)$ & $($ Std. $=1.89)$ & \\
\hline \multirow{4}{*}{ Ineffective } & Group 2 & Group 4 & \multirow{4}{*}{$\begin{array}{c}(\mathrm{N}=25) \\
(\text { Mean=5.36) } \\
(\text { Std. }=3.27)\end{array}$} \\
\hline & $(\mathrm{N}=12)$ & $(N=13)$ & \\
\hline & (Mean=7.33) & (Mean=3.53) & \\
\hline & $(S t d .=2.17)$ & $(S t d .=3.20)$ & \\
\hline \multirow{3}{*}{ Total } & $(\mathrm{N}=28)$ & $(\mathrm{N}=23)$ & $(\mathrm{N}=51)$ \\
\hline & (Mean=6.82) & $($ Mean=5.21) & (Mean=6.09) \\
\hline & $($ Std. $=2.17)$ & $($ Std. $=3.30)$ & $($ Std. $=2.83)$ \\
\hline
\end{tabular}

fluencing fraudulent use of village funds under conditions is adverse selection compared to no adverse selection. Based on table 8, the test results show that the internal control system has a value of $\mathrm{F}=4,603$, and sig. 0.037 at the significance level of $5 \%$. Furthermore, adverse selection has a value of $\mathrm{F}$ $=4.199$, and sig. 0.046 . The findings of this

Table 8. Tukey Test Result

\begin{tabular}{cccc}
\hline Group & Mean Difference & Standard & Sig. \\
\hline 2 and 4 & 3.7949 & 0.97401 & $0.002^{* * *}$ \\
\hline 3 and 1 & 0.9625 & 0.98081 & 0.761 \\
\hline 3 and 4 & 3.8615 & 1.02341 & $0.002^{* * *}$ \\
\hline
\end{tabular}

study prove that the internal control system and adverse selection have an effect on fraudulent use of village funds. Furthermore, to test the second hypothesis (H2), the researcher compares group 2 and 4 . The results of the comparison of the two groups show that the mean difference is 3.7949, and sig. 0.002 at the $1 \%$ significance level. The mean value of the internal control system that is ineffective in the condition that there is adverse selection is higher than the mean value in the absence of adverse selection. The findings of this study prove that the internal control system that is not effective in influencing fraud in the use of village funds under conditions there is adverse selection compared to no adverse selection. Thus, the second hypothesis (H2) is supported.

Implementation of village head responsibilities to improve the welfare of village communities is often not done effectively. The reason is because the village head is often influenced by the presence of pressure, opportunity, and rationalization. These three factors are important elements of village head opportunistic behavior to commit fraudulent use of village funds. Needs or incentives to commit fraud, such as lifestyle needs, economic needs, external pressure. Situations or conditions that allow fraud to occur, such as ineffective internal control systems or abuse of authority occur because of opportunities, and attitudes or ethics that allow individuals to commit fraud and rationalize fraudulent acts as reasonable actions are used as a rationale for fraud. The village head as an agent will take advantage of opportunities in the form of ownership of information about the prospect of an organization with an ineffective internal control system to commit fraudulent use of village 
funds. Tehupuring and Lingga (2017) explains that the higher the internal control system, the lower accounting fraud. Conversely, the lower the internal control system, the higher accounting fraud.

Testing the third hypothesis ( $\left.\mathrm{H}_{3}\right)$, namely, the adverse selection condition does not affect fraudulent use of village funds when the internal control system is effective. Based on table 8 , the test results show that the internal control system has a value of $\mathrm{F}=4,603$, and sig. 0.037 at the significance level of $5 \%$. Furthermore, adverse selection has a value of $F=4.199$, and sig. 0.046. The findings of this study prove that the internal control system and adverse selection have an effect on fraudulent use of village funds. Next, to test the third hypothesis $\left(\mathrm{H}_{3}\right)$, the researcher compares group 3 and 1 . The results of the comparison between the two groups show that the mean difference is 0.9625 and sig. 0.761. The mean effective internal control system under conditions of no adverse selection is higher than the mean value in the condition of adverse selection. However, it is not significant. The findings of this study prove that adverse selection conditions (existing and non-existent) do not affect fraudulent use of village funds when the internal control system is effective. Thus, the third hypothesis ( $\left.\mathrm{H}_{3}\right)$ is supported.

The effectiveness of the implementation of the internal control system is the main key in preventing village heads from cheating the use of village funds, both in conditions of adverse selection and the absence of adverse selection.

Testing the fourth hypothesis $\left(\mathrm{H}_{4}\right)$, that is, in the absence of adverse selection, an effective internal control system will reduce fraudulent use of village funds compared to the ineffective internal control system. Based on table 8 , the test results show that the internal control system has a value of $\mathrm{F}=$
4,603, and sig. 0.037 at the significance level of $5 \%$. Furthermore, adverse selection has a value of $F=4.199$, and sig. 0.046. The findings of this study prove that the internal control system and adverse selection have an effect on fraudulent use of village funds. Next, to test the fourth hypothesis ( $\left.\mathrm{H}_{4}\right)$, the researcher compares group 3 and 4 . The results of the comparison of the two groups show that the mean difference is 3.8615 , and sig. 0.002 at the $1 \%$ significance level. The mean effective internal control system under conditions of no adverse selection is higher than the mean value of the ineffective internal control system in conditions of no adverse selection. The findings of this study prove that under no adverse selection conditions, an effective internal control system will reduce fraudulent use of village funds compared to ineffective internal control systems. Thus, the fourth hypothesis $\left(\mathrm{H}_{4}\right)$ is supported.

Lane and O'Connell (2009) explain that implementing an effective internal control system through the main focus of the system can reduce fraud in the organization. The strength of the implementation of the internal control system when applied effectively when compared to an internal control system that is not implemented effectively. An effective internal control system will reduce the likelihood of village heads in committing fraud. The village community will obtain information relating to the performance of the village organization. Although the village head has the authority to carry out village government activities, and has the potential to use his authority for personal interests, but if supported by an effective internal control system, it will prevent the village head's actions from misusing his authority. In other words, the implementation of the effectiveness of the internal control system is binding on the moral and ethics of the village head not to commit fraudulent use of village funds. 


\section{CONCLUSION}

In recent years, corruption cases at the village level have been in the public spotlight. This is evidenced through around 154 number of corruption cases at the village level involving 112 village heads, 32 village officials, and 3 people who are family heads of villages, resulting in state losses of 47.56 billion rupiah in 2015-2017. This case is carried out through various modes such as the practice of budget abuse, fictitious reports, fictitious activities/projects, and budget bubbles. These various modes occur because the internal control system is ineffective, so it provides an opportunity for actors to act opportunistically. The aim is to maximize his personal interests as agents rather than the interests of the community as principals. This opportunistic behavior is caused by the existence of information asymmetry. Information asymmetry creates conditions for obtaining information that is not aligned between the village head as an agent and the community as principal, so that the emergence of adverse selection emerges.

The findings of this study prove that (1) adverse selection conditions affect the relationship between the internal control system and fraudulent use of village funds; (2) the internal control system that does not effectively affect fraudulent use of village funds under adverse selection is compared to no adverse selection; (3) adverse selection conditions do not affect fraudulent use of village funds when the internal control system is effective; and (4) in conditions where there is no adverse selection, an effective internal control system will reduce fraudulent use of village funds compared to ineffective internal control systems. The description of the research findings provides several contributions such as the contribution of theory, methodology and policy.

The contribution of this study to the development of the theory is, the main cause of vil- lage heads to commit fraud in the use of village funds, namely, because of opportunities and rationalization. An ineffective internal control system is an opportunity for village heads to commit fraudulent use of village funds. In addition, if the village head has more information than the community, the village head has the potential to fulfill his interests rather than the interests of the community's welfare. The village head who committed fraudulent use of village funds felt that the action he did was right. This can happen because village heads involved in corruption cases have continued to increase over the past three years, so this condition can be used as a justification for corruption of village funds. Therefore, this study is able to provide confirmation of the fraud triangle theory, information asymmetry between village heads and the community provides opportunities for village heads to opportunistic behavior to fulfill their interests. To reduce this condition, an effective internal control system needs to be applied consistently. This can be known through the findings of this research. Thus, this research is able to contribute to agency theory.

The results of this study have contributed to the research methodology, namely, (1) the use of scenarios or research modules because this study uses laboratory experimental research, so as to be able to control irrelevant variables and reduce decisionmaking bias; and (2) experimental methods yield higher results related to the causal relationship between the dependent and independent variables, so the essence of this method depends on the researcher manipulating the independent variables and observing their impact on the dependent variable while controlling for other disturbing factors. Therefore, researchers need a strong theoretical foundation that is relevant to the research topic (Nahartyo, 2013).

The contribution of this study to policy is 
that regulators need to design an internal control system in accordance with the specific objectives of village government organizations by considering several important aspects, namely the planning process, the implementation process, the process of procuring goods and services related to the distribution and management of village funds, accountability processes, and monitoring and evaluation processes. These five processes are prone to fraudulent use of village funds, so the regulator is not only focused on increasing village fund allocation. However, it must focus more on securing village funds, so that the community as principals can enjoy justice and prosperity.

The limitations of this study are this study only uses Pattimura University accounting students who are taking a bachelor's degree as a subject. This is because the researcher takes into account the adequacy of the subject in each group, so that researchers do not use strata students as subjects because they are relatively few, and researchers only examine in terms of internal control systems and agency conflicts by referring to phenomena or corruption cases that occur at the village level, without taking into account other factors. However, other factors have been controlled by researchers through the superiority of the experimental method. Thus, further research is expected to be able to expand research subjects such as strata students by taking into account the adequacy of subjects in each group, and researchers can use other factors that can influence fraudulent use of village funds by using various corruption cases at the village level which the researcher has described in the introduction.

\section{REFERENCES}

Ahriati, D., Basuki, P., \& Widiastuty, E. (2015). Analisis pengaruh sistem pengendalian internal, asimetri informasi, perilaku tidak etis dan kesesuaian kompensasi terhadap kecenderungan kecurangan akuntansi pada Pemerintah Daerah Kabupaten Lombok Timur. Jurnal InFestasi, 11(1), 4155 .

Albrecht, S. W., \& Albrecht, C. (2004). Fraud examination and prevention. Australia: Thomson, South-Western.

Arens, A. A., \& Loebecke, J. K. (1996). Auditing: pendekatan terpadu. Buku Satu. Edisi Bahasa Indonesia. Jakarta: Salemba Empat.

Arnold, D., \& Ponemon, L. (1991). Internal auditor's perceptions of whistleblowing and the influence of moral reasoning: an experiment. Auditing: A Journal of Practice and Theory, 10(2), 1-16.

Bernardi, R., \& Guptill, S. (2008). Social desirability response bias, gender, and factors influencing organizational commitment: An international study. Journal of Business Ethics, 81(4), 797-809.

Boynton, W. C., Johnson, R. N., \& Kell, W. G. (2002). Modern auditing. Jakarta: Erlangga.

Campbell, D. T., \&. J. C. Stanley. (1966). Experimental and quasi-experimental designs for research. Boston, Mass: Houghton Mifflin Company.

Dewi, K. Y. K., \& Ratnadi, N. M. D. (2017). Pengaruh pengendalian internal dan integritas pada kecenderungan kecurangan akuntansi satuan kerja perangkat daerah Kota Denpasar. EJurnal Akuntansi Universitas Udayana, 18(2), 917-941.

Eisenhardt, K. M. (1989). Agency theory. An assessment and review. The Academy of Management Review, 14(1), 57-74.

Frilia, F., Agusti, R., \& Savitri, E. (2015). Pengaruh asimetri informasi, sistem pengendalian intern, dan kesesuaian kompensasi terhadap kecenderungan kecurangan akuntansi: Studi empiris pada bank swasta di Kota Pekanbaru. Jurnal Online Mahasiswa Fakultas Ekonomi Universitas Riau, 2(1), 1-15.

Ghozali, I. (2006). Aplikasi analisis multi- 
variate dengan Program SPSS. Semarang: Badan Penerbit Universitas Diponegoro.

Government Regulation Number 8 of 2016 on the Second Amendment to Government Regulation Number 60 of 2014 (Peraturan Pemerintah Nomor 8 Tahun 2016 Tentang Perubahan Kedua atas Peraturan Pemerintah Nomor 60 Tahun 2014). Retrieved from https:// jdih.kemenkeu.go.id/fullText/2016/ 8TAHUN2016PP.pdf.

Gusmaini, W., Fauziati, P., \& Yulistia, R. (2014). Pengaruh sistem pengendalian internal, sistem kompensasi, dan asimetri informasi terhadap kecenderungan kecurangan akuntansi. E-Jurnal Bunghatta, 5(1), 1-13.

Hartman, B. (2014). Effects of internal control system on fraud in banks. Internal Journal of Financial Stability, 2(3), 45 -50 .

Ikatan Akuntan Indonesia. (2012). Standar akuntansi keuangan. Jakarta: Salemba Empat.

Indonesia Corruption Watch. (2018). Outlook Dana Desa 2018 Potensi Penyalahgunaan Anggaran Desa di tahun Politik. Indonesia.

Jensen, M. C., \& Meckling, W. H. (1976). Theory of the firm: Managerial behavior, agency cost, and ownership structure. Journal of Financial Economics, 3 (4), 305-360.

Krismadji. (2008). Sistem informasi akuntansi. Yogyakarta: AMP YKPN.

Lane, R., \& O'Connel, B. T. (2009). The changing face of regulator's investigations into financial statement fraud. Accounting Research Journal, 22(2), 118-143.

Lestari, N. K. L., \& Supadmi, N. L. (2017). Pengaruh pengendalian internal, integritas dan asimetri informasi pada kecurangan akuntansi. E-Jurnal Akuntansi Universitas Udayana, 21 (1), 389-417.

Liyanarachi, G., \& Newdick, C. (2009). The impact of moral reasoning and retaliation on whistle-blowing: New Zeland evidence. Journal of Business Ethics, 89(1) 37-57.

Muna, B. N., \& Harris, L. (2018). Pengaruh pengendalian internal dan asimetri informasi terhadap kecenderungan kecurangan akuntansi: penelitian persepsi pengelola keuangan pada perguruan tinggi negeri BLU. Jurnal Akuntansi, Ekonomi dan Manajemen Bisnis, 6(1), 35-44.

Nahartyo, E. (2012). Desain dan Implementasi Riset Eksperimen Edisi 1. Semarang: UPP STIM YKPN.

Nahartyo, E. (2013). Desain dan Implementasi Riset Eksperimen Edisi 2. Semarang: UPP STIM YKPN.

Nahartyo, E., \& Utami, I. (2015). Panduan praktis riset eksperimen. Jakarta: Indeks.

Narsa, N. P. D. H. R., \& Supriyadi. (2017). Peran kode etik perusahaan dalam memitigasi perilaku eskalasi manajer berbingkai teori keagenan. Prosiding Simposium Nasional Akuntansi XX, Jember, Indonesia.

Nurhayati., \& Muniarty, P. (2018). Pengaruh sistem pengendalian internal dan asimetri informasi terhadap kecenderungan kecurangan akuntansi serta dampaknya terhadap kualitas laporan keuangan. Jurnal Ilmiah VALID, 15(2), 125-135.

Puspasari, N., \& Suwardi, E. (2012). Pengaruh moralitas individu dan pengendalian internal terhadap kecenderungan kecurangan akuntansi. Prosiding Simposium Nasional Akuntansi $X V$, Banjarmasin, Indonesia.

Randiza, I., Kamaliah., \& Anisma, Y. (2016). Pengaruh pengendalian internal, asimetri informasi, moralitas aparat pemerintah dan ketaatan aturan terhadap kecenderungan kecurangan akuntansi: Studi kasus pada SKPD Kabupaten Indragiri Hilir. Jom Fekon, 3 (1), 1108-1122.

Regulation of the Minister of Finance of the 
Republic of Indonesia Number 257/ PMK.07/2015 on Procedures for delays and/or deductions of balancing funds to regions that do not meet village fund allocation (Tata cara penundaan dan/atau pemotongan dana perimbangan terhadap daerah yang tidak memenuhi menimbang mengingat alokasi dana desa). Retrieved from http:// ditjenpp.kemenkumham.go.id/arsip/ bn/2015/bn2055-2015.pdf.

Regulation of the Minister of Finance of the Republic of Indonesia Number 49/ PMK.07/2016 concerning Procedures for allocation, distribution, use, monitoring and evaluation of village fund (Tata Cara Pengalokasian, Penyaluran, Penggunaan, Pemantauan dan Evaluasi Dana Desa). Retrieved from http:// www.jdih.kemenkeu.go.id/fullText/ 2016/49 PMK.07 2016Per.pdf.

Regulation of the Minister of Finance of the Republic of Indonesia Number 50/ PMK.07.2017 concerning management of transfers to regions and village funds as amended by Regulation of the Minister of Finance Number 112/ PMK.07.2017 (Pengelolaan Transfer ke Daerah dan Dana Desa). Retrieved fromhttp://www.jdih.kemenkeu.go.id/ fullText/2017/50 PMK.07 2017Per.p df.

Rest, J. R. (1986). Moral development: Advances in research and theory. Newyork: Praeger.

Ruankaew, T. (2013). The fraud factors. International Journal of Management and Administrative Science, 2(2), 1-5.

Setiawan, M. D., Adiputra, I. M. A. P., \& Yuniarta, G. A. (2015). Pengaruh sistem pengendalian intern, asimetri informasi, dan keadilan organisasi terhadap kecurangan: Studi empiris pada bank perkreditan rakyat se-Kabupaten Buleleng. E-Journal S1 Akuntansi Universitas Pendidikan Ganesha, 3(1), 18.

Scott, W. R. (2015). Financial accounting theory. Seventh Edition. Toronto:
Pearson Prentice Hall.

Tehupuring, R., \& Lingga, R. A. (2017). Sistem pengendalian intern sebagai prediktor kecurangan akuntansi pada pemerintah daerah. Dapatkah loyalitas individu memitigasinya? Jurnal Tata Kelola dan Akuntantabilitas Keuangan Negara, 3(2), 113-129.

Thoyibatun, S. (2009). Faktor-faktor yang berpengaruh terhadap perilaku tidak etis dan kecenderungan kecurangan akuntansi serta akibatnya terhadap kinerja organisasi. Ekuitas: Jurnal Ekonomi dan Keuangan, 16(2), 245260.

Triasmara, R. R. M., \& Anna, Y. D. (2014). Pengaruh efektivitas pengendalian intern, kesesuaian kompensasi dan asimetri informasi terhadap kecenderungan kecurangan pada PT. Telekomunikasi Indonesia, Tbk. EProsiding of Management, 1(3), 437451.

Tunji, S. T. (2013). Effective internal controls system as antidote for distress in the banking industry in Nigeria. Journal of Economics and International Business Research, 1(5), 106-121.

Wainaina, S. W. (2011). An evaluation of the internal control function: The case of Kenya polytechnic University Collage. University of Nairobi.

Wanjohi, M. W. (2014). Fraud in the banking industry in Kenya: A case of Commercial Bank of Africa, Kenya. United States International University Africa. 